\title{
Accrued Gains are not Income: An Administratively Simple Rollover Treatment for Capital Gains Taxation
}

\author{
Raymond L. Richman ${ }^{1}$, Jesse T. Richman ${ }^{2} \&$ Howard B. Richman ${ }^{3}$ \\ ${ }^{1}$ Professor Emeritus, Graduate School of Public and International Affairs, University of Pittsburgh, Pittsburgh, \\ PA, USA \\ ${ }^{2}$ Department of Political Science, Geography, and International Studies, Old Dominion University, Norfolk, VA, \\ USA \\ ${ }^{3}$ Research Associate, Ideal Taxes Association, Pittsburgh, PA, USA \\ Correspondence: Jesse Richman, Department of Political Science and Geography, BAL 7000, Old Dominion \\ University, Norfolk VA 23529, USA. Tel. 757-683-3853. E-mail: jrichman@ odu.edu
}

Received: September 17, 2020

Accepted: October 24, $2020 \quad$ Online Published: November 5, 2020

doi:10.5539/ijef.v12n12p1

URL: https://doi.org/10.5539/ijef.v12n12p1

\begin{abstract}
This paper presents a definition of income that rejects both the BEA and Haig-Simons definitions concerning capital gains. Specifically, capital gains represent future income unless brought to the present by consumption of the gain. We demonstrate that the rollover treatment implied by this definition ends double-taxation, under-taxation, lock-in of capital, excessive incentives to consume capital, and other economic distortions. Finally, we detail an administratively-simple deferred gain account rule for the rollover treatment which would require that taxpayers only track one additional item of information - the total deferred gain that would be rolled over into the next tax year.
\end{abstract}

Keywords: capital gains taxation, rollover treatment, timing neutrality, economic theory

JEL classification: H21 efficiency, optimal taxation, H24 personal income and other nonbusiness taxes and subsidies.

\section{Introduction}

Arguably the appropriate definition of income ought to guide income tax policy concerning the taxation of capital gains. While all definitions of income agree that wages, rents, profits and interest qualify as income, they differ as to whether capital gains are income. Of the two leading definitions, one excludes all capital gains in the income calculation while the other includes all capital gains in the income calculation:

1) The Bureau of Economic Analysis (BEA). This definition excludes capital gains from its definition of national income. When used to guide income tax policy, it leaves all capital gains untaxed.

2) Haig-Simons (Simons, 1938). This definition considers any appreciation in wealth, including capital gains, to be income. Strictly interpreted, it taxes capital gains at the end of the year in which they are accrued (mark-to-market) whether realized or unrealized, but Simons believed that administrative considerations required that the tax be levied against realized gains only.

Current U.S. capital gains tax policy might be said to split the difference between these definitions. In practice, Congress arrived at a complex treatment which only taxes capital gains when realized and then taxes capital gains earned by households at lower rates than those applied to normal income.

The purpose of this paper is to correct the errors made by both definitions and by current U.S. capital gains policy concerning when capital gains should be counted as income, and also to present a simple and feasible tax policy consistent with an appropriate consideration of when capital gains are - and are not - income.

Our definition of income builds upon the work of Hicks (1939) and Richman (1957) to define capital gains as the result of changes in the expected value of future income. This implies that gains should only face taxation as present income if, instead of waiting for the gain to become income in the future, the taxpayer elects to both realize the gain and consume it. Taxation should be deferred on capital gains that are realized but then rolled-over (i.e., kept invested). 
A key distinction between our proposal and the alternatives is its neutrality with respect to the timing of income. Because of this neutrality, we demonstrate that a system which adheres to the rollover principle can be used to avoid the challenges that perennially face capital gains taxation including double-taxation, under-taxation, incentives for the consumption of capital, lock-in, and speculative bubbles, and we discuss solutions to the problems posed by tax shelters, inflation and inheritance. Under our proposal, all investment income, including capital gains that are income, is taxed once, and all such income is taxed at the same tax rate.

We are advocating consistent taxation of income, not taxation of consumption. Some advocates of the rollover treatment have seen it as a compromise between a consumption tax and an income tax (Andrews, 1974; Blum, 1986). In contrast, we see the rollover treatment as the optimum way to implement an income tax. Our definition holds that capital gains represent changes in the expected value of future income. Therefore, when consumed, capital gains should be taxed at the same tax rate as ordinary income (Note 1).

We begin by defining capital gains and when such gains are present income. Next we discuss the three definitions of income and their associated capital gains treatments. As part of our discussion of the Hicks-Richman definition, we show how it achieves neutrality regarding the timing of income and develop the reduced-record-keeping version of the rollover treatment of capital gains taxation first proposed by Andrews (1974). Finally, we will discuss how the rollover treatment can eliminate the economic distortions that result from the current tax treatments of capital gains.

\section{Income and Capital Gains}

We begin with an analysis of the value of a capital asset, building from the standard approach for calculating the present value (Varian 1987, p. 191). In this framework, capital value is simply a constant plus the present value of the future income expected to result from ownership:

$$
\text { Asset value }=\mathrm{C}_{0}+\mathrm{Y}_{1} /(1+\delta)^{1}+\ldots+\mathrm{Y}_{\mathrm{n}} /(1+\delta)^{\mathrm{n}}
$$

Here $\mathrm{C}_{0}$ represents that part of value which is irrespective of the income stream, $Y_{l}$ is the expected after-tax yield in year one, $Y_{n}$ is anticipated income in year $n$, and $\delta$ represents the discount factor reflecting market expectations concerning interest and risk. In other words, capital value is the discounted value of anticipated future returns, adjusted for risk (Note 2).

If capital value is the present value of the yields expected from ownership of an asset, what is a capital gain? In his magisterial work Value and Capital, Hicks (1939) described capital gains as "windfall gains" that is, gains which were not anticipated:

The income ex post of any particular week cannot be calculated until the end of the week, and then it involves a comparison between present value and values which belong wholly to the past. On the general principle of "bygones are bygones," it can have no relevance to present decisions. The income which is relevant to conduct must always exclude windfall gains [italics added]; if they occur, they have to be thought of as raising income for future weeks (by the interest on them) rather than as entering into any effective sort of income for the current week. Theoretical confusion between income ex post and ex ante corresponds to practical confusion between income and capital. (p. 179)

For Hicks, unexpected changes in the expected income stream produce capital gains, and such gains are not part of ex-ante income. One indicator of their status as-such is that they have not been relevant for conduct - they have not been used for consumption.

Raymond L. Richman (1957) took this argument further: "A capital gain, to the extent that it is not illusory, is the capitalized value of a change in prospective yields" (p. 151). Again, a capital gain represents a change in the present value of future yields; it reflects a change in anticipated future income.

Richman's argument suggests that a capital gain can be represented by something akin to the derivative of the equation for capital value:

$$
\text { Capital gain }=\mathrm{dY}_{1} /(1+\mathrm{r})^{1}+\ldots+\mathrm{dY}_{\mathrm{n}} /(1+\mathrm{r})^{\mathrm{n}}
$$

where $d Y_{l}$ represents an unexpected change in returns in the first year and $d Y_{n}$, the unexpected change in income for year n. For example:

Suppose an investor purchases a business asset for $\$ 10,000$, which reflects forecasted annual income of $\$ 1,000$. However, the first year of income exceeds expectations by $\$ 500$ because of good luck, excellent management, and/or innovation, yielding a total return of $\$ 1,500$. Because the factors which led to better-than-anticipated returns are now expected to continue, they result in a parallel increase in the capital value of the asset to $\$ 15,000$, the original $\$ 10,000$, plus the $\$ 5,000$ accrued gain in present 
value associated with the additional $\$ 500$ in annual income (Note 3).

In other words, since capital values represent the present value of anticipated yields, capital gains are the result of changes in the expected income stream (Note 4).

Our analysis has implications for tax treatment. Accrued gains in capital value typically do not reflect current income - they result from changes in the expected value of future income. In a system of income taxation, therefore, capital gains should not be taxed as current income, unless the capital gain is consumed. Capital gains should be taxed as current income only if the increase in future income represented by the capital gain is converted into present income through consumption of the capital gain.

\section{Income Definitions and Tax Treatments}

The two leading definitions of income provide inconsistent and flawed prescriptions for the tax treatment of capital gains. In contrast, the Hicks-Richman definition leads to a feasible, simple, and efficient rollover tax regime.

\subsection{Haig-Simons Definition of Income}

The Haig-Simons definition of income holds that capital gains are always income in the present. Simons (1938, p. 61) quoted the definition offered by Haig (1921): "Income is the money value of the net accretion to one's economic power between two points in time." In the Haig-Simons definition, all changes in value (negative or positive) experienced by an investor's capital assets, both realized and accrued (i.e., unrealized or paper gains), ought to be included in the current year income.

Most critically, Haig and Simons' definition of personal income includes accrued gains. This implies that changes in capital value should be taxed immediately as ordinary income. The problem with this treatment is that it results in the double taxation of some income - capital gains that are kept invested. When accrued gains are taxed, then future income is taxed twice, unless the income never happens because the gain is realized and consumed:

Suppose that the investor of our previous examples, who raised the value of a business from $\$ 10,000$ to $\$ 15,000$, were taxed on both income and accrued gain at a 25 percent tax rate. The first year, this investor would pay a $\$ 375$ tax on the $\$ 1,500$ income as well as the capital gains tax of $\$ 1,250$ on the $\$ 5,000$ capital gain, for a total tax payment of $\$ 1,625$, which is more than this investor's total income of $\$ 1,500$ for the year! This payment could force the investor to sell the investment in order to pay the tax bill. If not forced to sell the investment, then over the course of ensuing years this investor would again pay the $\$ 1,250$ capital gains tax, this time in installments of $\$ 125$ per year on the $\$ 500$ in annual income that the capital gain represented. The investor would have paid a 50 percent tax on that capital gain (Note 5).

The accrual treatment thus double-taxes future income. Italy attempted to implement the accrual treatment with the Italian Tax Reform of 1998 (Alworth et al., 2003) with results that can only be described as farcical. At first stock prices increased, partly because of falling interest rates. Mutual funds found themselves liquidating their capital in order to pay the tax bill. Then stock markets crashed and mutual funds saw their tax credits build up, in some cases exceeding 50 percent of the value of the fund. Some funds feared that withdrawal of investor capital could leave them totally insolvent, with only tax credits for assets. A new government coalition quickly came to power promising to end the experiment. As Alworth et al. noted, the problems would have been even worse had Italy not had a very low rate of capital gains taxation.

Since accrual taxation is clearly not practicable, applications of the Haig-Simons definition, including the U.S. tax code, have usually taxed capital gains only when they are realized. Simons (1938, p. 47) recognized that this compromise was necessary, claiming that realization is "indispensable to a feasible income-tax system." But taxing realized gains only partially addresses the double-taxation problem. It continues double-taxation whenever realized gains are reinvested:

Suppose that the investor of our previous examples, who raised the value of a business from $\$ 10,000$ to $\$ 15,000$, plans to reinvest the capital gain of $\$ 5,000$ after selling the business for $\$ 15,000$. If the realized gain were taxed at a 25 percent rate, the investor would only have $\$ 13,750$ to reinvest. Since the purchaser of the asset invested $\$ 15,000, \$ 1,250$ of financial capital has disappeared into the government's hands. It is hard to avoid the conclusion that the $\$ 1,250$ is a tax on capital not income.

Tax codes that implement the realization treatment, including the current U.S. personal income tax code, tend to tax long-term capital gains at about half the rate that normal income is taxed (Minas 2019). However, as we 
discuss next, a preferential rate on capital gains creates its own perverse incentives for the consumption of capital.

\subsection{BEA Definition of Income}

For purposes of income calculation, the Bureau of Economic Analysis defines income as wages, rents, profits and interest. Capital gains are not counted in the calculation of national income. Similarly, until 1965, the British purposely excluded capital gains from taxation because they considered them to be capital, not income. Johnson (2009), quoting original sources, explained their reasoning:

A widely cited explanation for the exclusion of capital gains was that "[i]ncome tax ... is a tax on income. It is not meant to be a tax on anything else.” The explanation leaves something to be desired for those looking for an explanation of why money from capital gains was not income. The House of Lords later found an implied exclusion for capital gains, notwithstanding the literal wording of the income tax act, on the ground that Parliament "never ... intended to tax capital." Gain from capital was just considered to be capital for reasons that seem to have been hard to articulate. "Capital" is defined as amounts "not "consumed' immediately," but "contribut[ing] a quota to the national wealth." Capital gains, within the British thinking, were considered to be still investment or wealth. (p. 489)

In their Flat Tax proposal, Hall and Rabushka (2007) revived the British reasoning. They explained why they considered capital gains to be capital, not income:

The market value of the stock is the capitalization of its future earnings. Because the owners of the stock will receive their earnings after the corporation has paid the business tax, the market capitalizes after-tax earnings. A capital gain occurs when the market perceives that prospects for after-tax earnings have risen. When the higher earnings materialize in the future, they will be correspondingly taxed. In a system like the current one, with both an income tax and a capital gains tax, there is double taxation. (p. 111-112).

Although this logic has something in common with our reasoning above, it is worth exploring it more deeply in order to see the problems associated with using this definition of income to guide income taxation of capital gains without a separate treatment of consumed gains such as the one we propose. The British (until 1965) and Hall and Rabushka were correct that the value of capital represents future income since it capitalizes prospects for future after-tax earnings. They were also correct that when capital gains from invested capital are taxed, there is a double-tax on income (as we demonstrated above). However, they failed to notice that when capital is being consumed, future income is being consumed in the present while escaping payment of taxes.

Therefore, a zero tax rate on capital gains allows the future income that would be produced by a capital gain to go completely untaxed, but only if it is consumed before it is earned:

Suppose that the investor of our examples (who we will call Investor 1), sells the business to Investor 2 for $\$ 15,000$, and consumes the $\$ 5,000$ capital gain tax free. Let's assume that, in the absence of this sale, Investor 2 would have invested the $\$ 15,000$ in some other venture paying a comparable (10 percent) rate of return. Thus, in the absence of the sale (and consumption of the gain by the seller), a total of $\$ 30,000$ in capital would have been invested yielding a return of $\$ 3,000$ per year. But after this sale, only $\$ 25,000$ is invested, yielding a return of $\$ 2,500$ per year. If both investors continue to pay income taxes at a 25 percent rate, then expected government tax revenue per year from income taxation before the sale and consumption of the gain would have been $\$ 750$. After the sale and consumption of the gain, however, government revenue would be only $\$ 625$ (Note 6).

The zero tax rate on capital gains not only encourages the consumption of future income in the present, but it also encourages tax avoidance if one can convert profit or interest income into capital gains. During the period when capital gains went untaxed in Britain, the authors of a 1954 Memorandum of Dissent to a Royal Commission report described many of the ways that owners of capital were then converting profits and interest income into untaxed capital gains (Titmuss, 1962).

\subsection{Income Definition and the Rollover Treatment}

Hicks' and Richman's insight that prospective gains are not current income agrees with the BEA definition that unrealized accrued capital gains are not income at all - that capital gains that are not consumed but are reinvested are not income. But the BEA definition is incorrect concerning situations in which a capital gain is realized and consumed. In this case future income has been brought to the present. Since consumed capital gains are future income that has been realized and consumed in the present, it ought to be taxed in the present, else it will not be taxed at all. 
Johnson (2009), like us, recognizes that capital gains that are consumed should be taxed differently from capital gains that are reinvested. His solution is to tax capital gains that are reinvested at a preferred tax rate. But the appropriate tax treatment for capital gains under the Hicks-Richman definition is the "rollover" treatment (Clark, 1958; Andrews, 1974; Blum, 1986) which lets capital gains be reinvested without incurring any income tax liability, thus keeping the capital intact.

Here is how the rollover treatment of capital gains works when taxpayers buy $\$ 10,000$ worth of stock (or any other asset) and sell it for $\$ 15,000$. Tax deferral is conditional on the decision to reinvest the capital:

1) If investors reinvest the entire $\$ 15,000$, they pay no tax. Instead, the reinvested capital gain is rolled-over into the new asset and taxation is deferred at least until a future sale.

2) If investors do not reinvest any of the capital in other assets, then they pay taxes at ordinary income tax rates on the full $\$ 5,000$ capital gain.

All versions of the rollover treatment agree with the above two propositions. Their differences occur when capital is only partially reinvested and when taxpayers have portfolios of assets that they are buying and selling during the same tax year. Among the three rules for applying the rollover treatment that have been proposed, the best and most feasible is the deferred gain account rule, to be described below, which simplifies record keeping and enforcement and insures that capital gains taxes are paid as soon as the taxpayer consumes the capital gain.

\subsubsection{First in First Out Rule}

The First In First Out (FIFO) rule has been used when the rollover treatment has been applied by the U.S. tax code. It requires the tracing of a capital gain from the asset sold to the asset or assets to which the capital gain had been rolled over. It is currently specified in the rollover treatment for sales of qualified small business stock in Section 1045 of the U.S. tax code, as summarized by GROCO (2014):

Enacted as part of the Taxpayer Relief Act of 1997 (effective for sales after August 5, 1997), a taxpayer other than a corporation may elect to roll over capital gains from the sale of qualified small business stock held for more than six months if other small business stock is purchased by the individual during the 60-day period beginning on the date of sale.

Accordingly, gain is recognized only to the extent that the amount realized on the sales exceeds the cost of replacement small business stock purchased during the 60-day-period, as reduced by the portion of such cost, if any, previously taken into account. To the extent that capital gain is not recognized, that amount will be applied to reduce the basis of the replacement small business stock. The basis adjustment is applied to the replacement stock in the order such stock is acquired (FIFO).

The FIFO rule has the problem that it changes the basis of the new assets that are purchased, making taxpayers responsible for keeping a record of each basis.

\subsubsection{Pro Rata Rule}

Clark (1958) advocated the pro-rata rule - the first rule that generalized the rollover treatment to asset portfolios. Reinvested gains would be apportioned to the basis of all assets purchased during that same tax year. Here is how Clark described that rule:

$[R]$ einvested gains would be applied to reduce the cost basis of assets purchased during the same tax year on a pro-rata basis, that is, in the same proportion that the purchase price of each new asset bears to total purchases for the year. One year-end overall arithmetical computation by the taxpayer would be all that would be necessary in addition to existing procedures for computing gains and losses. (p. 163)

The pro-rata rule would require that taxpayers keep track of two separate pieces of data on every asset purchased: (1) the purchase price and (2) the deferred capital gain that had been rolled over into that asset. When assets were sold, the deferred gain would be subtracted from the purchase price in order to compute the tax basis of those assets.

As with the FIFO rule, the taxpayer would be responsible for keeping track of the amount of deferred capital gain rolled over into each asset purchase, making it difficult for taxing authorities to police capital gains tax cheating, as David (1968) wrote:

Simplicity for the taxpayer does not mean corresponding ease of tax administration. The accounting required would be more difficult to police than under taxation on realization, since the market does not provide an automatic check on the amount of appreciation in any individual's portfolio. The price of an asset on the date of purchase is not generally the basis of property sold. Thus tax administrators are not 
able to verify the basis of property sold by checking the published prices of securities. Verification requires that the taxpayer maintain a record of gains allocated in the year of purchase (p. 203)

The other problem with the pro-rata rule is that it would almost always prevent full taxation of the capital gain. In order for that to occur, taxpayers would have to fully liquidate every stock to which the original capital gain had been rolled over.

\subsubsection{Deferred Gain Account Rule}

Andrews (1974) was the first to suggest the deferred gain account rule as a way to simplify administration of investment portfolios under the rollover treatment. In his Footnote 142, he wrote:

A more general approach would be to credit deferred gains to a general deferred gain account, to be returned to income in any subsequent year in which aggregate disinvestments exceed aggregate investments (both computed on a cash flow basis, taking loan proceeds and repayments into account as well as asset sales and purchases). (p. 1179)

We have found no subsequent discussions of the rollover treatment that have built upon Andrews' insight, so until now it seems to have been forgotten in favor of less practical alternatives. A somewhat similar idea in the context of a much larger tax reform is the ZT-account proposal in a recent working paper by Ingles (2019).

As with the pro-rata rule, the purchase would need to be made during the same tax year as the sale, but taxpayers could be given extra time to make the purchase, just as individual taxpayers have extra time to make their IRA contributions. Calendar-year taxpayers could, at their option, attach asset purchases and loan repayments made between January 1 and April 15 to the previous tax year.

In contrast to both of the other rules, only one item of information would need to be kept in order to calculate the basis for the sale of a non-depreciable asset - that item would be its purchase price, making it easy for taxing authorities to police capital gains for common stocks.

A single number, the end-of-year balance of the deferred gain account, would be calculated on each year's tax form by the capital gains taxpayer, whether household, corporation or fiduciary trust, and carried over to the next tax year. Taxation would be simple. The first step would be to add net capital gains realized during that tax year to the balance of the deferred gain account. The second step would depend upon which of three conditions apply:

1) Negative deferred account balance. If the deferred gains account balance is less than zero, the taxpayer would have experienced a capital loss which would be treated the same way that a capital loss is treated under the current tax law.

2) Capital being accumulated. If the total of net purchases of assets minus net borrowing on assets is a positive number or zero during a tax year, no capital gains tax would be paid.

3) Capital being consumed. If the total of net borrowing on assets minus net purchases of assets is a positive number, tax would be paid on the total (and the balance of the deferred gain account reduced) until the point is reached where balance of the deferred gain account reaches zero. (Any further consumption of capital would not be consumption of capital gains, and would not be subject to taxation.)

\section{Economic Distortions}

After publishing about a dozen papers on the realization and accrual tax treatments of capital gains, Auerbach (2010) concluded that neither of the treatments that follow from the Haig-Simons definition of income is both viable and feasible:

The realization principle is no longer a viable approach to taxation, but full accrual taxation is not yet feasible and alternatives to it face political resistance. (p. 70)

In contrast, the rollover tax treatment that follows from the Hicks-Richman definition of income is both viable and feasible. It would solve the problems of the current U.S. capital gains tax without taxing capital gains twice and without encouraging investors to consume their capital.

\subsection{Intertemporal Neutrality}

Of the three definitions of income, only one is neutral with regard to the timing of income. As shown in Table 1, and discussed above, both the Haig-Simons definition and the BEA definition discriminate against future income as compared to present income due to their treatment of capital gains. 
Table 1. Capital gains taxation under alternative definitions of income

\begin{tabular}{|c|c|c|c|}
\hline $\begin{array}{l}\text { Definition of income } \\
\text { (tax treatment) }\end{array}$ & Consumed capital gain & Capital kept invested & $\begin{array}{l}\text { Neutrality with respect to timing of } \\
\text { income }\end{array}$ \\
\hline BEA & No tax. & Capital gain taxed once. & $\begin{array}{l}\text { Under-taxation of consumed gain } \\
\text { creates incentive for disinvestment. }\end{array}$ \\
\hline $\begin{array}{l}\text { Haig-Simons } \\
\text { (accrual form) }\end{array}$ & Capital gain taxed once. & Capital gain taxed twice. & $\begin{array}{l}\text { Double-taxation of invested gain } \\
\text { creates incentive for disinvestment. }\end{array}$ \\
\hline $\begin{array}{l}\text { Haig-Simons } \\
\text { (realization form) }\end{array}$ & Capital gain taxed once. & $\begin{array}{l}\text { Capital gain taxed twice if realized and } \\
\text { reinvested. }\end{array}$ & $\begin{array}{l}\text { Double taxation of reinvested gain } \\
\text { creates incentive for disinvestment. }\end{array}$ \\
\hline $\begin{array}{l}\text { Hicks-Richman } \\
\text { (rollover treatment) }\end{array}$ & Capital gain taxed once. & Capital gain taxed once. & $\begin{array}{l}\text { Income associated with all gains taxed } \\
\text { once. }\end{array}$ \\
\hline
\end{tabular}

A tax system based upon the BEA definition of income encourages the consumption of future income in the present. A system based upon the Haig-Simons definition, tends to the double-taxation of future income, first as increases in the value of capital, then as the income produced by the capital gain. Particularly under an accrual taxation regime, this also encourages consumption of future income in the present because such consumption is the only way to avoid double taxation.

Under the Hicks-Richman definition of income and the resultant rollover treatment, if the capital gain is kept invested so that it produces future income, that future income will be taxed in the future at normal rates. If the capital gain is consumed so that the future income that it represents is never realized, then that capital gain is taxed in the present at normal rates. The Hicks-Richman definition is the only one of the three definitions of income that is neutral with regard to the timing of income.

\subsection{Lock-in Effect}

The lock-in effect (Holt \& Shelton, 1962; Globan \& Škrinjarić, 2020) is a well-established result of the realization treatment of capital gains taxation. It prevents investors from moving capital from one investment to another without tax penalty and thus tends to tie up capital in less-productive investments.

In an experimental study, Meade (1990) found that the rollover treatment eliminates this effect. Her subjects were 65 experienced investors. Each participated in a computerized investment game in which subjects allocated points between a lock-in investment and a new risky investment. The different tax treatments were simulated by the way management fees were assessed in the game. Each subject played all conditions (5 conditions with two tax rates). She found:

1) The realization treatment locks-in capital and prevents it from being made available to risky investments.

2) Lowering capital gains tax rates mitigates the lock-in effect for the realization treatment and results in more capital being made available to risky investments.

3) Both the accrual and the rollover treatments reduce the lock-in effect as compared to the realization treatment.

4) The rollover treatment reduces the lock-in effect more than the other treatments and also makes capital more readily available to risky investments.

\subsection{Tax Shelters that Convert Normal Income to Capital Gains}

Low capital gains tax rates incentivize investors to purchase or engineer tax shelters that convert income into ersatz capital gains (Richman, 1960; McIntyre, 1984). Indeed, the indirect contribution of capital gains taxation to revenues, by preventing tax shelters, could be greater than the actual yield of the capital gains tax, according to Littlewood (2017):

In all of the countries examined in this book, the taxation of capital gains has made only a relatively modest contribution to government revenues - typically around 1 per cent of total revenues. Or, at least, the direct contribution of capital gains taxes to revenues has been relatively modest.

It is also possible, however, that these capital gains taxes have made a substantial indirect contribution to revenues by protecting the income tax base - that is, by deterring taxpayers from adopting arrangements designed to convert taxable income into non-taxable capital gains. This is, however, very difficult to measure (pp. 6-7).

According to David (1968) tax shelters that convert profits into capital gains become more and more prevalent as 
the disparity between the tax rates on capital gains income and on normal income increase:

The incentives to convert profits, dividend payments, and other returns to entrepreneurial activity into the form of capital gains would become progressively greater as the margin between capital gains and ordinary income taxation was widened. Taxpayers could and would take advantage of this difficulty of defining eligible transactions to convert their receipts into capital gains (p. 199).

Because the rollover treatment would end the differential between the rate at which normal income and capital gains income are taxed, it would greatly reduce the use of these tax shelters.

\subsection{Angel of Death Loophole}

Under current law, many taxpayers take their accrued gains with them to the grave and the estate of the taxpayer does not pay capital gains tax. Burman (1999) considers this to be a loophole that would be exacerbated by the rollover treatment. Beyond estate taxes themselves, however there are ready alternatives that could be used to ensure that the capital gain accrued by the deceased would not escape taxation:

1) Pass on the deferred gain account with the assets. The purchase prices that the deceased had paid for assets could be passed on to the heirs and the balance of the deferred gain account of the deceased could be distributed to the balances of the deferred gain accounts of the heirs in proportion to their inheritance of the assets.

2) Consider the purchase price of inherited assets to be zero. An administratively simple alternative proposed by Andrews (1974) would simply consider the basis of all inherited assets (other than those passed on to spouses or minor children) to be zero, making the entire sales price of inherited assets a capital gain if consumed.

These provisions would not require heirs to sell an income producing business, farm, or other asset, in order to pay a capital gains tax. However, if they did sell the asset and consume the proceeds their tax payments would equal (alternative one) or exceed (alternative two) the taxes which would have been due in an equivalent situation for the decedent. A rolled-over capital gain would not be taxed until consumed and could continue to produce taxable income which would be taxed at ordinary rates.

\subsection{Illusory Capital Gains Due to Inflation}

The rollover treatment that we recommend in this paper does not exclude illusory capital gains due to inflation, which tend to become large when an asset is held for a long time period or when the inflation rate is high. Because it reduces lock-in, as discussed above, the negative consequences of illusory capital gains would be reduced by the rollover treatment. Beyond this, an accurate adjustment could be obtained by indexing capital gains for inflation. The purchase price of an asset could be converted to current dollars, and the capital gain could be calculated in current dollars. This is already being done successfully in India using a Cost Inflation Index reported by the Central Board of Direct Taxes (Sengupta, 2017).

\subsection{Loans with Assets as Collateral}

We have proposed that net loans, using assets as collateral, would be considered to be consumption of capital for the purpose of the rollover treatment. We did so in order to avoid a tax loophole, discussed by David (1968):

[C]onsumption could be financed indirectly by loans against assets, in that case, capital gains taxes would not be paid in spite of the liquidation of the taxpayer's net worth (p. 205).

Our rollover treatment is based on the basic idea that whenever owners of assets start liquidating their assets, the first capital consumed should be considered to be capital gains and should be taxed as such. Once asset owners have liquidated their capital gains, they could liquidate the remainder of their capital free from capital gains taxation.

\subsection{Speculative Bubbles}

Capital gains taxes may discourage asset bubbles. Thomas Wiedmer (2002) found, employing an endogenous growth theory model, that when an economy is characterized by a bubble, the higher the tax rate, the smaller the asset bubble. However, Lei et al. (2002) found that asset price bubbles can still be produced in the laboratory in the presence of capital gains taxation at high rates. 


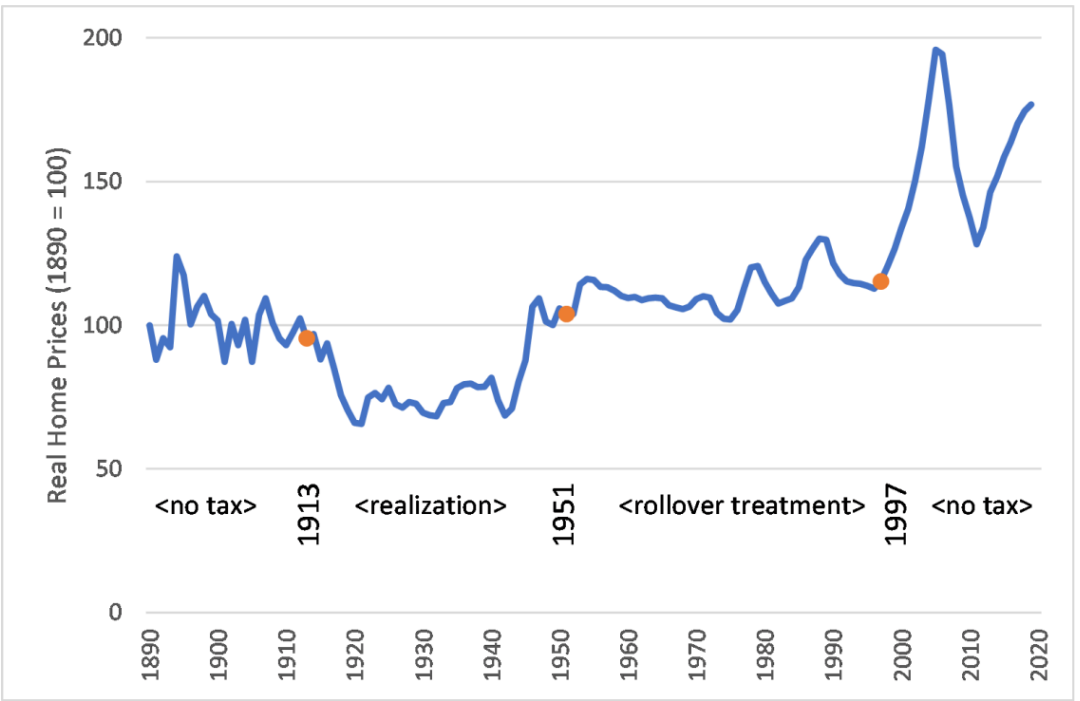

Figure 1. Robert J. Shiller's Real Home Price Index

Source: Calculated from Sale and Resale of Same Homes by Shiller (2018).

Capital gains for home sales were first taxed, through the realization treatment, when Congress began the current income tax system in 1913. The rollover tax treatment was in place for home sales in the U.S. from 1951 to 1997 , and the zero tax treatment has been in place since 1998 when homes are sold for up to $\$ 500,000$. As shown in Figure 1, real house prices (purchases and sales of the same houses) were stable during the entire 46 year period that the rollover treatment was in effect, but immediately went into an asset bubble in 1998, the year when it was replaced by the zero tax rate treatment.

There were other factors that contributed to this bubble as well, including the low mortgage rates of the period and the increasing securitization of mortgages, but economic-bubble expert Vernon L. Smith (2007) named it the "Clinton Housing Bubble" after the President who was in office when the new treatment was enacted. He argued that President Clinton and Congress should have kept the rollover treatment for homes and extended it to include other assets as well. He wrote:

More daring than the action to exempt real estate from the capital gains tax - and in lasting service to the poor - would have been actions allowing capital gains on all assets to go tax free, provided that the capital was reinvested - i.e., not consumed.

The rollover treatment encouraged the psychology of wealth accumulation. A table in 2013 dollars published by Wolff (2016, p. 27), shows that during the rollover treatment, median household wealth rose steadily from $\$ 55.5$ thousand in 1962 to $\$ 83.5$ thousand in 1989. In contrast, by 2013, following the end of the rollover treatment in 1998 , median household net wealth had fallen to $\$ 63.8$ thousand. Rollover opponent Klein (1998) pointed out:

For almost half a century, the rollover rule created a powerful incentive for home sellers to buy up to qualify for tax deferral. Every year, over four million families sell their homes. Many complied with the buy-up prerequisite, with fewer than $4 \%$ of home sales triggering tax liability for capital gains. (p. 405)

In contrast, the new zero tax rate on capital gains led to a very different psychology on the part of investors. During the bubble, people purchased houses, not just for their utility, but with the expectation of selling them later and receiving a huge tax free capital gain that they could consume. As Richman (1960) pointed out, when capital gains are taxed at a lower rate than normal income, speculation is encouraged:

$[\mathrm{M}]$ any individuals purchase securities and property with the "expectation" of realizing capital gains which, however unhappy it may make the economist, the individual considers spendable. There is no need to detail this point. We are exposed on all sides to the solicitations of brokers and financial services to purchase securities in the hopes of realizing capital gains. The advertisements on the financial pages speak for themselves. The rampant speculative (defined as the purchase of securities for gains rather than yields) fever reaches into the investment clubs, and does not need to be documented. (p. 598)

The middle class wealth accumulation of the 1951-1997 period might have partly resulted from the rollover treatment of taxation on capital gains from home sales which encouraged an attitude of wealth accumulation. 
The decline in median wealth that followed may have partly been due to the zero tax rate treatment which encouraged a speculative approach to house purchases and gave the home purchasers an incentive to consume capital.

\section{Summary}

In this paper we have recovered the insights of Hicks (1939) and Richman (1957) to develop a revised definition of income with regards to capital gains:

1) The BEA definition excludes all capital gains from being counted as income, asserting that no changes in asset values should be considered changes in income.

2) The Haig-Simons definition counts all capital gains as income, asserting that all changes in asset values should be considered changes in income.

3) The Hicks-Richman definition treats capital gains as present income only if the investor treats it as income -- if the capital gain is consumed in the present.

The BEA definition, when applied to capital gains can encourage the consumption of capital. It leaves capital gains untaxed if the capital that produced those gains is consumed in the present, but taxes the income produced by capital that is kept invested. In addition, it leads to the proliferation of tax shelters which convert profits into capital gains in order to avoid taxation on those profits. Also, it fails to restrain asset bubbles.

In its pure form the Haig-Simons definition implies the accrual treatment of capital gains taxation, which is a double-tax upon the increased income associated with the gain. Income is first taxed when the capital gain accrues and again taxed when the increased income produced by the gain is taxed. Beyond this double-taxation problem, the accrual treatment does not work in practice because it forces some asset owners to liquidate their capital in order to pay their tax bills.

When the Haig-Simons definition is applied via the realization treatment it creates many new difficulties including: (1) the double taxation of income that is realized and then reinvested, (2) the lock-in effect, (3) tax shelters that convert profits into capital gains, (4) the angel-of-death tax loophole, (5) taxation of illusory capital gains due to inflation, and (6) the use of loans to consume capital gains without taxation.

In this paper, we elucidate a third definition, the Hicks-Richman definition that capital gains are the result of changes in the expected future income stream. This definition recognizes that in most but not all instances capital gains are not present income. They only become present income when future income is brought into the present through realization followed by consumption of the capital gain (Note 7).

The Hicks-Richman definition and the resulting rollover treatment avoids many of the pathologies of the alternative capital gains tax treatments because it is the only treatment which exhibits neutrality concerning the taxation of income across time. If the capital gain that represents future income is consumed in the present, it is taxed at normal rates in the present. If the capital gain that represents future income is kept invested, the future income is taxed at normal rates.

Past efforts to expand the rollover treatment to common stocks have been rejected due to the administrative complexity of the rules that were advocated. In this paper, we develop an administratively-simple deferred gain account rule, suggested for the rollover treatment by William (1974), which would require that taxpayers only track one additional item of information - the total deferred gain that would be rolled over into the next tax year. This treatment:

- Eliminates the lock-in effect which locks capital into less-productive investments.

- Minimizes the use of tax shelters that convert profits into capital gains to take advantage of lower capital gains tax rates.

- Can be used to end the "Angel of Death Loophole" from capital gains taxation

- Can be indexed to prevent taxation of illusory capital gains due to inflation.

- Minimizes the use of loans to avoid capital gains taxation.

The rollover treatment encourages a psychology of wealth accumulation in which people sell assets and then roll over the proceeds into more expensive assets in order to qualify for tax deferral. During the 46 years that it was applied to home sales in the United States, middle class households grew steadily in wealth. In contrast, the taxation of capital gains at preferred rates creates a psychology of speculation in which people purchase assets for gains instead of for yields or utility. The zero tax rate treatment that followed the rollover treatment contributed to a house price bubble and a decline in middle class wealth. 
The chief benefit of the rollover treatment would occur in the long-term. No longer would the government double-tax capital gains, first as capital and then as income. No longer would the tax code favor consumption of capital gains in the present over reinvestment to produce income in the future. The Hicks-Richman definition provides a coherent view of income which distinguishes between income and capital and produces a rational rollover treatment that taxes the income associated with all capital gains once.

\section{References}

Alworth, J., Giampaolo, A., \& Roni, H. (2003). What's Come to Perfection Perishes: Adjusting Capital Gains Taxation in Italy. National Tax Journal, 56(March). https://doi.org/10.17310/ntj.2003.1s.04

Andrews, W. D. (1974). A Consumption-Type or Cash Flow Personal Income Tax. Harvard Law Review, 87, 1128-40. https://doi.org/10.2307/1340076

Auerbach, A. J. (2010). Directions in Tax and Transfer Theory. In Proceedings of Future Tax and Transfer Policy Conference a Conference (pp. 63-71). Melbourne Institute of Applied Economic and Social Research.

Blum, C. (1986). Rollover: An Alternative Treatment of Capital Gains. Tax Law Review, 41, 383-458.

Burman, L. E. (1999). The Labyrinth of Capital Gains Tax Policy: A Guide for the Perplexed. Washington DC: Brookings Institution Press.

Caginalp, G., David, P., \& Vernon, L. S. (2000). Overreactions, Momentum, and Price Bubbles in Laboratory and Field Asset Markets. The Journal of Psychology and Financial Markets, 1, 24-48. https://doi.org/10.1207/S15327760JPFM0101_04

Clark, R. (1958). An Alternative for Capital Gains Taxation: A 'Rollover' Account for Investment Assets. Howard Law Review, 4, 157-169.

David, M. (1968). Alternative Approaches to Capital Gains Taxation. Washington: The Brookings Institution.

Globan, T., \& Tihana, Š. (2020). Penny wise and pound foolish: Capital gains tax and trading volume on the Zagreb Stock Exchange. Public Sector Economics, 44(3). https://doi.org/10.3326/pse.44.3.2

GROCO. (2014). Sec. 1045: Small Business Stock Rollover of Gain. Retrieved from http://www.groco.com/readingroom/sec1045_rollover.aspx

Haig, R. M. (1921). The Concept of Income. In R. M. Haig (Ed.), The Federal Income Tax. New York.

Hall, R. E., \& Alvin, R. (2007). The Flat Tax (2nd ed.). Stanford CA: Hoover Institution Press.

Hicks, J. R. (1939). Value and Capital. Oxford: Clarendon Press.

Himmelberg, C., Christopher, M., \& Todd, S. (2005). Assessing High House Prices: Bubbles, Fundamentals, and Misperceptions. Cambridge MA: National Bureau of Economic Research, Working Paper 11643. https://doi.org/10.3386/w11643

Holt, C. C., \& Shelton, J. P. (1962). The Lock-In Effect of the Capital Gains Tax. National Tax Journal, 15(December), 337-52.

Ingles, D. (2019). Taxing capital income and the Z-tax solution. Tax and Transfer Policy Institute Working Paper. https://doi.org/10.2139/ssrn.3396228

Johnson, C. H. (2009). Taxing the Consumption of Capital Gains. Virginia Tax Review, 28, 477-529.

Klein, C. A. (1998). A Requiem for the Rollover Rule: Capital Gains, Farmland Loss, and the Law of Unintended Consequences. Washington \& Lee Law Review, 50, 403-446.

Lei, V., Noussair, C., \& Plott, C. R. (2002). Asset Bubbles and Rationality: Additional Evidence from Capital Gains Experiments. Social Science Working Paper 1137, California Institute of Technology, Pasadena, CA.

Littlewood, M. (2017). Capital Gains Taxes-A Comparative Survey. In M. Littlewood, \& C. Elliffe (Eds.), Capital Gains Taxation: A Comparative Analysis of Key Issues (pp. 1-29). Edward Elgar Publishing, Cheltenham, UK. https://doi.org/10.4337/9781784716028.00009

McIntyre, R. S. (1984). Just Taxes \& Other Options. Less Taxing Alternatives, (March).

Meade, J. A. (1990). The Impact of Different Capital Gains Tax Regimes on the Lock-In Effect and New Risky Investment Decisions. The Accounting Review, 65(2), 406-431.

Minas, J., (2019). The Implications of Capital Gains Tax Rate Preferences. Oxford University Press. 
Richman, R. L. (1957). A Contrast of American and British Income Taxation. Unpublished doctoral dissertation, Department of Economics, University of Chicago.

Richman, R. L. (1960). Incentive Effects of Alternative Tax Treatments of Capital Gains. Proceedings of the Annual Conference on Taxation under the Auspices of the National Tax Association, 53, 597-603.

Richman, R. L. (1961). Reconsideration of the Capital Gains Tax - A Comment. National Tax Journal, 14, 402-04.

Richman, R., Howard, R., \& Jesse, R. (2008). Trading Away Our Future: How to Fix Our Government-Driven Trade Deficits and Faulty Tax System Before it's Too Late. Ideal Taxes Association, Pittsburgh, USA.

Sengupta, D. P. (2017). India. In M. Littlewood, \& C. Elliffe (Eds.), Capital Gains Taxation: A Comparative Analysis of Key Issues (pp. 363-401). Edward Elgar Publishing, Cheltenham, UK.

Shiller, R. (2005). Irrational Exuberance (2nd ed.). Princeton NJ: Princeton University Press. https://doi.org/10.1016/s0378-4266(02)00285-6

Shiller, R. J. (2018). Online Data Robert Shiller. Retrieved from http://www.econ.yale.edu/ shiller/data.htm

Simons, H. C. (1938). Personal Income Taxation. Chicago: The University of Chicago Press.

Smith, V. L. (2007). The Clinton Housing Bubble. Wall Street Journal (December 18).

Stiglitz, J. E. (1990). Symposium on Bubbles. Journal of Economic Perspectives, 4, 13-18. https://doi.org/10.1257/jep.4.2.13

Titmuss, R. M. (1962). Income Distribution and Social Change: A Study in Criticism. George Allen \& Unwin, London, UK.

Varian, H. (1987). Intermediate Microeconomics: A Modern Approach. New York: W.W. Norton and Company. https://doi.org/10.1057/978-1-349-95121-5_1212-1

Wiedmer, T. (2002). Taxation, Asset Bubbles, and Endogenous Growth. Jahrbucher fur Nationalokonomie und Statistik, 222, 500-507. https://doi.org/10.1515/jbnst-2002-0407

Wolff, E. N. (2016). Household Wealth Trends in the United States, 1962 to 2013: What Happened over the Great Recession. Russell Sage Foundation Journal of the Social Sciences, 2(6), 24-43. https://doi.org/10.7758/rsf.2016.2.6.02

\section{Notes}

Note 1 . We implicitly hold in this paper that all types of income should be taxed at the same rate. We set aside arguments which hold that society should encourage or discourage one or another type of income by taxing different kinds of income at different rates.

Note 2. By assumption, the summation represented in Equation 1 includes the prospective yields over the life of the asset. Consequently, we reject all models which include expected capital gain in the calculation of capital value. Indeed, we think such models are likely to tempt analysts into foolish speculations. For example, during price bubbles investors pay more for an asset than its fundamental value because of an incorrect notion that they can expect a capital gain (Stiglitz, 1990; Caginalp et al., 2000). Similarly, New York Federal Reserve senior economist Charles Himmelberg and his co-authors (Himmelberg et al., 2005), at the very height of the 1998-2006 house price bubble, incorrectly claimed that house prices were not in bubble because homeowners could expect annual capital gains. In contrast, Shiller (2005), in his book Irrational Exuberance, correctly claimed that house prices were indeed in a bubble. His simple assumption, which he demonstrated graphically in market after market, was that capital values, after adjusting for inflation and earnings growth, do not change much in the long run (see Figure 1 for an example), indicating that capital gains and losses tend to balance each other out. We agree with Shiller's apparent finding that only inflation and earnings growth tend to cause capital gains in the long run, except that we would also add changes in the discount rate adjusted for risk.

Note 3. Example adapted from Richman et al. (2008, chapter 5).

Note 4. The passage of time will sometimes bring about these changes, as in the cases of growth stocks and recently planted orchards where the capital gain can result from the updating of the capital value after the Y1 period has passed, bringing closer the period in which the increased future income will occur.

Note 5. In the example above the asset was kept invested and so a double tax is paid. To see that the tax is only paid once if the capital gain is consumed, consider this example. Suppose that the owners of a firm receive the 
surprise news that a $\$ 10$ windfall will allow the firm to pay an additional one-time dividend next year (by paying the dividend, the firm is turning the windfall into present income). The stock value will increase by the present value of this $\$ 10$. In a mark-to-market system, this increase will be taxed now. In the following year, the dividend will be paid. However, the payment of this one-time dividend (i.e. the translation of the capital gain into income) will also decrease the value of the stock. This capital loss will offset the dividend (i.e. income) next year so that the income is only taxed once. Hence, consumption of the gain avoids double taxation, whereas keeping a gain invested creates the opportunity for double taxation.

Note 6. This example assumes that corporate and/or individual tax policies are structured such that 25 percent of business income is paid in taxes. The argument made through this example does not depend upon the specific tax policies applied to current year business income, so long as there is some tax on this income.

Note 7. The Hicks-Richman definition does not lead to a general consumption tax. Under a consumption tax, individuals can fund an investment account with pre-tax current income (e.g. from dividends, labor, or other sources). Our proposal does not allow this. All our proposal does is to allow the individual to maintain ownership of current assets (or transfer ownership to other assets of the same value) without paying a tax on capital.

\section{Copyrights}

Copyright for this article is retained by the author(s), with first publication rights granted to the journal.

This is an open-access article distributed under the terms and conditions of the Creative Commons Attribution license (http://creativecommons.org/licenses/by/4.0/). 